\title{
Human genetics, natriuretic peptides and hypertension
}

\author{
Christopher Newton-Cheh ${ }^{1,2}$ \\ From 5th International Conference on cGMP: Generators, Effectors and Therapeutic Implications \\ Halle, Germany. 24-26 June 2011
}

\section{Background}

Hypertension (HTN) is a major worldwide cause of stroke, heart failure, myocardial infarction, and chronic kidney disease. Human genetics offers the potential to identify novel physiologic mechanisms that underlie blood pressure (BP). BP is a heritable trait but until recently genetic factors that influence $\mathrm{BP}$ at the population have been difficult to identify.

\section{Results}

We used a candidate gene association study of common variants across the NPPA-NPPB locus to identify genetic variants that influence atrial natriuretic peptide (ANP) and B-type natriuretic peptide (BNP) [1]. The minor alleles of three noncoding SNPs rs5068 (MAF 0.06), rs198358 (MAF 0.19) and rs632793 (MAF 0.38) were associated with higher ANP $(+0.42$ SD $\mathrm{p}=8 \times 10-70 ;+0.20$ $\mathrm{p}=8 \times 10-30 ;+0.08 \mathrm{p}=2 \times 10-10$, respectively) and higher BNP $(+0.17$ SD $\mathrm{p}=3 \times 10-12,+0.18 \mathrm{p}=9 \times 10-25,+0.21$ $\mathrm{p}=2 \times 10-68)$ in 14,515 individuals of European ancestry. The alleles of rs5068 and rs198358 associated with higher ANP/BNP were associated with lower SBP $(\mathrm{p}=2 \times 10-6, \mathrm{p}=6 \times 10-5$, respectively) and lower $\mathrm{DBP}$ $(\mathrm{p}=1 \times 10-6, \mathrm{p}=5 \times 10-5)$ as well as lower odds of HTN (OR $0.85 \mathrm{p}=4 \times 10-5$, OR $0.90 \mathrm{p}=2 \times 10-4$ ) in 29,717 individuals. The association of rs5068 was replicated in the Global BPgen GWAS [2]. Recently, Kato et al reported the association of a common variant downstream of NPR3 encoding the natriuretic peptide clearance receptor [3]. Murine NPR3 knockout is associated with lower $\mathrm{BP}$, consistent with higher levels of circulating natriuretic peptides [4]. The minor allele of a SNP highly correlated to the BP NPR3 SNP has recently been reported to be associated with taller stature in humans [5],

Correspondence: cnewtoncheh@chgr.mgh.harvard.edu

${ }^{1}$ Massachusetts General Hospital, Boston, MA, USA

Full list of author information is available at the end of the article consistent with the effect of murine knockout [4] or apparent loss-of-function mutations [6] in NPR3.

\section{Conclusion}

The ANP-BNP/pGC/cGMP axis is important in the regulation of BP in humans. Further ongoing GWAS studies have identified additional novel loci. Human genetics can offer an entrée into the physiologic determinants of blood pressure at the population level and point to therapeutic opportunities to reduce the morbidity and mortality due to HTN.

\section{Author details}

${ }^{1}$ Massachusetts General Hospital, Boston, MA, USA. ${ }^{2}$ Broad Institute of Harvard and MIT, Cambridge, MA, USA.

Published: 1 August 2011

\section{References}

1. Newton-Cheh C, Larson MG, Vasan RS, Levy D, Bloch KD, Surti A, Guiducci $C$, et al: Association of common variants in NPPA and NPPB with circulating natriuretic peptides and blood pressure. Nat Genet 2009, 41:348-353.

2. Newton-Cheh C, Johnson T, Gateva V, Tobin MD, Bochud M, Coin L, Najjar SS, et al: Genome-wide association study identifies eight loci associated with blood pressure. Nat Genet 2009, 41:666-676.

3. Kato N, Takeuchi F, Tabara Y, Kelly TN, Go MJ, Sim X, Tay WT, et al: Metaanalysis of genome-wide association studies identifies common variants associated with blood pressure variation in east Asians. Nat Genet 2011, 43:531-538.

4. Matsukawa N, Grzesik WJ, Takahashi N, Pandey KN, Pang S, Yamauchi M, Smithies O: The natriuretic peptide clearance receptor locally modulates the physiological effects of the natriuretic peptide system. Proc Natl Acad Sci USA 1999, 96:7403-7408.

5. Lango Allen H, Estrada K, Lettre G, Berndt SI, Weedon MN, Rivadeneira F, Willer CJ: Hundreds of variants clustered in genomic loci and biological pathways affect human height. Nature 2010, 467:832-838.

6. Jaubert J, Jaubert F, Martin N, Washburn LL, Lee BK, Eicher EM, Guénet JL: Three new allelic mouse mutations that cause skeletal overgrowth involve the natriuretic peptide receptor $\mathrm{C}$ gene (Npr3). Proc Natl Acad Sci USA 1999, 96:10278-10283.

doi:10.1186/1471-2210-11-S1-05

Cite this article as: Newton-Cheh: Human genetics, natriuretic peptides and hypertension. BMC Pharmacology 2011 11(Suppl 1):O5.

\section{Biomed Central}

( 2011 Newton-Cheh; licensee BioMed Central Ltd. This is an open access article distributed under the terms of the Creative Commons Attribution License (http://creativecommons.org/licenses/by/2.0), which permits unrestricted use, distribution, and reproduction in any medium, provided the original work is properly cited. 